УДК 347.781 .51

\title{
THE COPYRIGHT PROTECTION IN THE CONSTRUCTION SPHERE
}

\author{
Kh. Tarasenko \\ Ivan Franko National University of Lviv, \\ 1, Universytetska Str., 79000, Lviv, Ukraine, \\ e-mail: khrystyna.ch@gmail.com
}

Nowadays, all the results of the author's intellectual and creative activity in the construction sphere require proper legal regulation that can eliminate unfair contractual practices, prevent the misuse of intellectual property. The author analyzes such forms of copyrightprotection in the construction sphere as self-defense («settlement out of court») and the protection of copyright within the limits of judicial jurisdiction and emphasizes on the fact that the self-defense of the copyright of an architect, a design organization is preceded by the discovery of the violation rights to a particular object, for example, to a project of the shopping center facade design. Thus, the right-holder or his representative has the right to address the offender the requirement to stop the commission of actions that violate his rights and eliminate the negative consequences of such violation and/or pay compensation. Such a settlement may be «finished» by concluding an agreement on the granting of a permit for the use of acopyright object or by paying compensation on voluntary basis. It has been argued that the most effective and most commonly used form of copyright protection is the appeal to the court with the demand to recover compensation for copyright infringement. This is due to the fact narrower subsubject proof. The plaintiff shall prove only the fact of infringement.

Keywords: copyright, protection, construction, judicial defense, self-defense.

Introduction. In the light of the modern technology and multi-faceted creative work, the sphere of construction is thoroughly permeated with copyright objects. Building companies compete for the client, offering an extravagant look and "smart" technology. Both for designing and for the operation of construction equipment or for the management of the "smart house» system, appropriate software is used - computer programs and data intended to solve a certain range of tasks stored digitally. In the world, the era of 3D construction begins, in which building 3D printers will «print» (build) practically everything that will be set as the output data in the computer program managing such a printer. Today, despite the relative «youth» of such technology, it has attracted the attention of both the European Space Agency and NASA planning to start the construction of space bases on other planets using such $3 \mathrm{D}$ printers.

Issue formulation. Today, all the results of the author's intellectual and creative activity in the construction sphere require proper legal regulation that can eliminate unfair contractual practices, prevent the misuse of intellectual property by others. In addition, it is important to provide proper legal protection in case of copyright infringement. Therefore, there are such issuesconcerning the possibility of self-defense and the protection of rights by court as the forms and methods of intellectual property rights protecting in the field of construction. The court practice has ambiguously solved these issues. Therefore, the current state of affairs requires a comprehensive scientific study.

Recent research and publications analysis. Nowadays, there are few scientists paying attention to the research of intellectual property rights protection in the constructing sphere. These are as follows: Y. A. Grekov («Author's supervision in the construction sphere as an element of copyright protection of a work of architecture», (2007) [1], E. Yu. Gnatchenko

(C) Tarasenko Kh., 2017 
(«Legislation Architecture work», (2013) [2], O. P. Novitsky (the main area of research is intellectual property in the field of construction, but mostly on the technical side) [3], V. V. Pysseva (research topics - the use of objects of patent law in construction) [4] and others. However, most of these studies are of general natureand do not highlight intellectual property protection in the construction sphere comprehensively and thoroughly. There are also no monographic studies in this area. Textbooks on intellectual property rights do not pay attention to this issue. Therefore, this issue leaves a wide field to research.

Objectives of the article: to identify the most relevant and effective forms and methods of copyright protecting in the construction sphere, highlight their specifics, and clarify the role of an advocate in the process of copyright protecting in the context of recent legislative amendments.

Main content of the article. Generally, there are such forms of intellectual property rights protection in the construction sphere as self-defense or settlement out of court and thecopyright protection within judicial jurisdiction. The following material we suggest to consider through individual legal situations.

Self-defense of an architect or design organization copyright is preceded by the discovery of the fact of violation of rights to a particular object, the project of the design of the facade of the mall, for example. Then, the right holder or his representative has the right to address the offender the requirement to stop the commission of actions that violate his rights and eliminate the negative consequences of such violation and pay the appropriate compensation. These actions may be qualifies as»settlement dispute out of court».On the one hand, one of the possible scenarios is the offender's positive response to the demand.In this case, parties may stipulate the duty of the offender to stop the violation and, for example, pay compensation, damages or the loss of benefit to the architect or the design organization.

The practice of concluding such agreements is not thoroughly analyzedneither in the scientific literature nor in judicial practice The issue remains open to research and arguing the same as the legal force and the execution of such a settlement out of court.

Firstly,it is advisable to acopyright holder to make a written claim. Despite the fact that the claim procedure is not binding in Ukraine (due to the fact that the court jurisdiction extends to all legal relations in the state) such a written document certifies the very fact of the violation (the proof of which shall be added to the claim letter) and proves the fact of detecting actions that violate the law. Secondly, the claim allows the offender to record the fact of the claims brought by the right holder (for example, the amount of compensation for the violation of copyright to the project of landscape design, the computer program, etc., that right holder requires).

The agreement concerning mutual rights and obligations of the copyright subject and the offender shall be concluded in writing. It will be the basis, for example, for the transfer of funds as compensation or indemnification. If the parties have agreed to pay compensation to the offender at a certain amount, we recommend the offender to make a cashless payment providing him with a payment document-proof of the transfer of funds in a certain amount. In this case, the offender shall indicate the purpose of the payment (details of the agreement - arrangements for settling the dispute) and keep such a payment document as proof of payment. In turn, the right holdershall provide the offender with a letter of guarantee on the absence of any claims in relation to this fact of the violation.

It is an arguable questionwhether the offender is «protected» from right holder's putting the case to court despite the agreement. In our opinion, in spite of settling a dispute out of court, the right holderis entitled to the right to turn to court. Then, the courtshall give an appropriate assessment of the agreement. 
However, the situation may turn to the other side. If the offender violates copyright, the project designer of the mall facade may forward a letter of claim, and the result of the negotiations will not be the payment of compensation or indemnification, but the contract permitting to use such a design project.

A similar opportunity to resolve a dispute out of court is provided to those of the construction industry, whose rights are violated within the Internet. New amendments to the Law of Ukraine «On Copyright and Related Rights» provides that in case of violation of any copyright committed with the use of the Internet, the copyright holder (hereinafter the applicant) has the right to contact the owner of the website and (or) a web page on which the appropriate electronic (digital) information is posted or otherwise used, with a statement of termination of the violation [5]. The applicant demands for termination of the violation solely by representation (mediation) of anadvocate. Having identified the applicant and the fact that he is entitled to such rights both with the documents proving the violation, the advocate sends the relevant application. Under the Law of Ukraine «On advocacy and advocate's activity», one copy of the documents certifying the powers of the lawyer to provide legal aid to the applicant shall be attached to the application. Having no grounds to reject the application, the website owner immediately, no later than 48 hours from the moment ofthe application receiving, shall terminate the violation and refuse the access to the electronic (digital) information providing the applicant and the provider of the hosting services information on the measures taken.

In our opinion, the above-mentioned amendments to the Law of Ukraine "On Copyright and Related Rights» regarding the possibility of settling a dispute outside the court through an advocate, if the rights of the rightholder are violated on the Internet, need to be improved, since the lawyer's monopoly in this category of cases is inappropriate.

Moreover, it is worth stressing about the cases of sites interception, the so-called cybersquatting - an illegal activity consisting in the registration, use and offering for sale of a domain name with a false intent to profit. This is performed through tracking the time when the term of registration of a domain name of a construction company expires; the company does not manage to order, and pay services for registering a domain name, even for a day (hour). Then the cybersquater registers the released domain for itself, subsequently offering it as a purchase to the real former owner of the site. The problem is that today this issue has not been resolved within the framework of the legislation. Thus, the cybersquattingis within the law because it is a registering of free domain. Nevertheless, such activities should be consideredin the light of general principles of civil law (fairness, reasonableness, integrity) as unfair business practice. As practice shows, construction companies are inclined to reach agreements with cybersquatters regarding the «purchase» of their domain name, which is carried out through its redelegation.

Ways of judicial protection of intellectual property rights in the construction sphere varies depending on the object of legal protection, and jurisdiction - depending on the parties to a dispute.

Both the copyright holder (the author of the construction project, the inventor of the latest method of foundation laying, the holder of the trade mark of building materials, etc.) and a patent attorney or other entitled representative (intellectual property advocate, profile lawyer, etc.) is empowered to turn to court for the protection of the infringed intellectual property rights.

It is worth paying more attention to the most widespread methods of copyright protection in the construction, because they constitute the most extensive segment of intellectual property rights in the constructionsphere.

Architectural projects, landscape design projects, exterior and interior design projects, architectural objects, computer programs and other objects are protected within 
the framework of copyright. Generally, the ways of copyright protectionin the structuring sphere are identical to those in other areas. Specificity lies in the proving process in the light of copyrightobjectpeculiarities.

There are such ways of copyright protection applicable by court:

- compensation of moral (non-property) damages inflicted by violation of intellectual property rights, with the determination of the amount of compensation;

- compensation of damages caused by infringement of intellectual property rights;

- revenue collection received as a result of violation;

- prohibition of the intellectual property object's use;

- compensation (10-50 000 minimum wages) instead of other material demands, provided by law.

Compensation is the most commonly used method of protection. Even if the courtbind the defendant to paymoral damages in favor of the plaintiff, the amount of those is rather low (ranging from one to four thousand hryvnia). Consideration and satisfaction of the material claim for damages or moral damages caused, for example, to the author of a landscape design project, requires tremendous efforts of proving. Thus, in accordance with the general grounds of civil liability, resolving a dispute regarding compensation for damage or moral damagesit is bindingto clarify: the existence of such damages; unlawful act of the perpetrator; the presence of a causal link between the damages and the unlawful act; presence of the perpetrator's fault.

It is worth stressing that the most difficult in proving is the fact of the existence of a causal link between the damages or moral damages to an individual or the business reputation of a legal entity and the defendant's conduct caused such damages. In addition, the court shallclarify actions (inaction) causeddamages, evidenceproving the fact of causing damages or moral damages, and estimate them.

The most common and practically justified ways of copyright protection in the construction sphere are court prohibition to illegal use of an intellectual property object and awarding compensation of 10-50,000 minimum wages, instead of other method of protection. This is because the plaintiff does not need to prove his right to compensation; he is entitled to him under the law.

Compensation shall be paid in case of proving the violation of the copyright subject'sproperty rights, but not the size of the damages caused.

Thus, in order to satisfy the claim for compensation, there shall be sufficient evidence that a person has committed actions infringing copyright; the plaintiff is not obliged to prove the amount of damages caused. At the same time, court considering the case anddetermining the amount of compensation shall take into account the amount damages caused.

Each separate fact of the illegal use of copyright objects, including the repeated use of the same object, is an independent violation and may be the ground for compensation.

The amount of compensation is determined by the court within the limits of the declared requirements depending on the nature of the violation, the extent of the defendant's fault and other circumstances.

In particular, the court shall take into account:

- duration of the violation and its volume (single or multiple use of copyright object);

- supposedamount of damages;

- amount of income received as a result of the offense;

- number of victims;

- intentions of the defendant;

- previously committed violations of the plaintiff' sexclusive right by the defendant;

- possibility to restore the previous state and the necessary efforts for that, etc. 
In practice, the requirement to prohibit further use of the copyright object and the claim for compensation are combined in one claim.

Conclusions. It is worth highlighting the following forms of copyright protection in the construction sphere: self-defense and judicial protection. The most effective and most often used form of copyright protection a lawsuit with a claim for compensation for copyright infringement, since in such a case the subject of proof is much narrower: the plaintiff shall prove only the fact of the violation; and compensation for such violation is guaranteed under the law.

\section{Список використаних джерел}

1. Греков С. А. Авторський нагляд в будівництві як елемент охорони та захисту авторського права на твір архітектури URL: http://www.ilf-ua.com/ua/publications/articles/avtorskiynaglyad/(дата звернення 22.09.2017).

2. Гнатченко С. Ю. Конспект лекцій 3 дисципліни «Законодавство і архітектурнопроектна справа» URL: http://www.eprints.kname.edu.ua/35079/1/2013\%2074Л\%20печ\%20\%203АПС.pdf (дата звернення 22.09.2017).

3. Новицький O. П. Інтелектуальна власність в будівництві URL: https://www.pdaa.edu.ua/sites/default/files/node/2793/novyckyyintelektualnavlasnistvbudivnyctvi.pdf (дата звернення 22.09.2017).

4. Писєва О. В. Деякі особливості ліцензійного договору на використання об'єктів патентного права в будівництві // Теорія і практика інтелектуальної власності. 2014. № 6. С. 70-76.

5. Про авторське право і суміжні права: Закон України від 23.12.1993 № 3792-XII URL: http://zakon2.rada.gov.ua/laws/show/3792-12 (дата звернення 22.09.2017).

\section{References}

1. Hrekov, Y. A. (2015). Avtorskyi nahliad v budivnytstvi yak element okhorony ta zakhystu avtorskoho prava na tvir arkhitektury, Retrieved from http://www.ilf-ua.com/ua/publications/articles/avtorskiynaglyad/

2. Hnatchenko, Y. Y. (2013). Konspekt lektsii z dystsypliny "Zakonodavstvo i arkhitekturnoproektna sprava». Retrieved from http://www.eprints.kname.edu.ua/35079/1/2013\%2074L\%20pech $\% 20 \% 20 Z$ ZPS.pdf

3. Novytskyi, O. P. (2015). Intelektualna vlasnist v budivnytstvi. Retrieved from https://www.pdaa.edu.ua/sites/novyckyyintelektualnavlasnistvbudivnyctvi.pdf

4. Pysieva, O. V. (2014). Deiaki osoblyvosti litsenziinoho dohovoru na vykorystannia obiektiv patentnoho prava v budivnytstvi, Teoriia i praktyka intelektual'noi vlasnosti, 6, 70-76.

5. Zakon Ukrainy pro avtorske pravo i sumizhni prava (1993). Retrived from http://zakon2.rada.gov.ua/laws/show/3792-12

Стаття: надійшла до редакції 28.09.2017 прийнята до друку 24.10.2017

\section{ЗАХИСТ АВТОРСЫКИХ ПРАВ У СФЕРІ БУДІВНИЦТВА}

\section{Х. Тарасенко}

Львівський національний університет імені Івана Франка, вул. Університетська, 1, 79000, Львів, Україна, e-mail:khrystyna.ch@gmail.com

Досліджено теоретичні питання щодо захисту авторських прав у сфрері будівництва. Проаналізовано чинне законодавство щодо правового регулювання відносин стосовно самозахисту та захисту авторських прав у судовому порядку. Проаналізовано теоретичні 
позиції з предмета дослідження та судову практику щодо вирішення спорів, пов'язаних із захистом авторських прав у сфері будівництва. Зроблено висновок, що інтелектуальна і творча діяльність авторів у сфері будівництва потребує належного правового регулювання, яке зможе усунути нечесну договірну практику, запобігти неправомірному використанню чужих інтелектуальних надбань, а в разі їх порушення - забезпечити можливість належного та ефективного захисту. Встановлено, що $є$ такі форми захисту авторських прав у сфері будівництва: самозахист та врегулювання спору поза судом і захист прав у судовому порядку (в порядку цивільного чи господарського судчинства). Доведено, що виявлення самим суб'єктом (його працівниками чи уповноваженими представниками) фракту порушення прав на конкретний об'єкт інтелектуальної власності передує самозахисту прав інтелектуальної власності архітектора чи проектної організації та є першим етапом в ініціюванні процесу захисту. Встановлено, що правоволоділець має право звернутися до порушника із вимогою про припинення вчинення дій, які порушують його права та усунення негативних наслідків такого порушення і (або) сплатити відповідну компенсацію. Наголошено про необхідність письмового оформлення такої вимоги. Обґрунтовано необхідність зазначення призначення платежу у разі безготівкового перерахування коштів як компенсації за порушення авторських прав, що забезпечить порушника належним та допустимим засобом доказування. Доведено, що позасудове врегулювання спору може завершитись укладенням договору про надання дозволу на використання об'єкта авторського права, сплатою компенсації в добровільному порядку. Встановлено, що зміни до Закону України «Про авторське право і суміжні права» щодо можливості врегулювати спір поза судом за посередництвом адвоката, якщо права правоволодільця порушені в мережі Інтернет, потребують доопрацювання, оскільки адвокатська монополія у цій категорії справ $є$ недоречною. Обґрунтовано, що найрезультативнішою та найчастіше застосовуваною формою захисту авторських прав у сфрері будівництва $є$ звернення до суду з матеріально-правовою вимогою про стягнення компенсації за порушення авторського права, оскільки в такому разі предмет доказування $€$ значно вужчим - позивач повинен довести лише сам фракт порушення, а компенсація за таке порушення гарантована йому законом.

Ключові слова: авторське право, захист, будівництво, судовий захист, самозахист. 